\title{
Farklı Sosyo-Ekonomik Statüye Sahip 8-10 Yaş Arası Çocukların Bazı Fiziksel ve Motorsal Özelliklerinin İncelenmesi*
}

\section{Investigation of Some Physical and Motoric Characteristics of Children Aged 8-10 Years With Different Socio- Economic Status}

Alper Karadağ ${ }^{\mathrm{a}, * *}$

${ }^{a}$ Muş Alparslan Üniversitesi Beden Eğitimi ve Spor Yüksekokulu, 49250, Muş / Türkiye ORCID: 0000-0002-8931-2523

\section{MAKALE BİLGİSI}

Makale Geçmişi:

Başvuru tarihi: 24 Mart 2019

Düzeltme tarihi: 20 Mayıs 2019

Kabul tarihi: 28 Mayıs 2019

\section{Anahtar Kelimeler:}

Çocuk,

Sosyo-Ekonomik Statü,

Fiziksel Gelişim,

Motorsal Performans
ÖZ

Bu çalışma, Ardahan İl'i merkezinde ilköğretim sürecine tabii olan farklı sosyo-ekonomik statüye sahip 8-10 yaş gurubundaki kız ve erkek çocukların bazı fiziksel ve motorsal performans profillerini incelemek üzere tasarlanmıştır. Çalışmaya ebeveynlerinin izni ile 239 kız ve 286 erkek olmak üzere toplam 525 çocuk iştirak etmiştir. Her bir çocuğun; boy, vücut ağırlığ1 ve vücut yağ yüzdesi ile durarak uzun atlama, el pençe kuvveti, esneklik, mekik çekme ve 5 x 10 m çeviklikle kombine edilmiş hız özellikleri ölçülmüştür. Çalışmaya katılan çocukların ailelerinin sosyo-ekonomik statülerini farklılaştıran toplam aylık gelirleri, anne ve babanın eğitim düzeyleri ile ikametgâh adreslerindeki farklılıklar ailelere sorulan sorulardan elde edilen cevaplar ile kategorilendirilmiştir. Çalışma neticesinde, ailelerin sahip olduğu sosyo-ekonomik statünün, çocukların fiziksel gelişimi ve bazı motorsal performans değerleri üzerinde olumlu / olumsuz etkiye yol açtığı tespit edilmiştir.

\section{ARTICLE INFO}

\section{Article history:}

Received 24 March 2019

Received in revised form 20 May 2019

Accepted 28 May 2019

\section{Keywords:}

Child,

Socio-Economic Status,

Physical Development,

Motoric Performance

\section{A B S T R A C T}

This study has been designed to investigate some physical and motoric performance profiles of male and female children aged between 8-10 with different socio-economic status and having primary education in the center of Ardahan province. A total of 525 children, including 239 girls and 286 boys have participated with the consent of their parents. Each child's height, weight, body fat percentage, standing long jump, hand grip strength, flexibility crunches and speed characteristics combined with $5 \times 10$ m agility have been measured. Their total monthly income differentiating the socio economic status of the children's families participated in the study, parents' education levels and differences in their residence address have been categorized with the answers obtained from questions asked to the families. As a result of the study, it has been found out that the families' socio economic status has positive / negative effects on children's physical development and some motoric performance values.

\section{Giriş}

Çocukların fiziksel ve motorsal (kuvvet, sürat, dayanıklılık, esneklik...) uygunluk göstergelerinin yaşlara göre olağan bir aralıkta seyretmesi, fiziksel ve motorsal bakımdan sağlıklı bir gelişim sürecinin temel göstergelerindendir. Çocuklarda fiziksel gelişim ve motorsal performans düzeyi ile sosyoekonomik göstergeler arasındaki ilişkiyi konu alan bu çalışma, Türkiye'nin Kuzeydoğusunda Gürcistan ve

Ermenistan'a sınırları olan, 1800 m rakıma sahip Ardahan ilinde gerçekleştirildi.

* Bu çalışma, 16-19 Nisan 2015 tarihlerinde ABD’nin Teksas Eyaletinin San Antonio Şehrinde düzenlenen Uluslararası Disiplinlerarası Çalışmalar Kongresinde bildiri olarak sunulmuştur.

${ }^{*}$ Sorumlu yazar/Corresponding author

e-posta: alper.karadag@alparslan.edu.tr 
Son yıllarda düzenli bir șekilde göç veren iller arasında olan Ardahan İlinin 2008 y1lında 112.242 olan nüfusunun 2018 yılı itibari ile 98.907 olduğu belirtilmiştir. Nüfusunun \% 44' ü 25 yaşının altında olan bu yerleşim merkezinin il ve ilçe merkez nüfusunun toplam nüfusa olan oranı $\% 35$ iken bu rakam Türkiye geneli için 2011 yılı itibariyle \% 76,8 olarak verilmiştir(01.03.2019)

https://biruni.tuik.gov.tr/ilgosterge/?locale=tr.

Çocuklarda gelişim süreci normal seyrinde devam ederken, fiziksel büyüme ve sinir sistemine bağlı olarak motor becerileri de gelişir. Kalıtım, sosyo-ekonomik durum, beslenme, ırk, vücut ölçülerinin olgunlaşma hızı gibi birçok faktör, çocukların motor becerilerindeki gelişimini etkilemektedir (Erden, 2009). Motor beceri gelişimi bakımından 6-9 yaş aralığı temel becerilerin kombinasyonlarından oluşan geçiş becerilerini (ip atlama, bisiklet, kickball), 10-12 yaş aralığı ise temel ve geçiş becerileri kombinasyonlarından oluşan (soccer kicking, gymnastics) özel becerileri kapsayan dönemlerdir (Larson vd., 1995). Geçiş evresi içerisinde yer alan 7-8 yaşlarındaki çocuklar temel hareket becerilerini daha kompleks ve özel formlara dönüştürebilir. $\mathrm{Bu}$ dönemde çocukların çeşitli hareket örüntülerini keşfetmesi, birleştirmesi ve gelişen hareket becerileri ile gurur duyması söz konusudur (Gallahue vd., 2002). Birçok çocuğun kaynakları sınırlı ortamlarda yaşaması gelişimsel olarak olumsuz sonuçlar doğurmaktadır. Gelişmekte olan ülkelerde kötü bir fiziksel büyümenin yaygın olduğu ve çocukların \% 38'inin düşük kilolu, \% 42'sinin ise k1sa boylu olduğu (Olness, 2003), bu oranların Amerika Birleşik Devletlerinde sırası ile \% 2 ve \% 1 olduğu belirtilmiştir (UNICEF, 2006).

Normal seyrinden daha kötü olan büyüme ve gelișimsel sonuçlar kısıtlı sosyal ve ekonomik kaynaklar ile ilişkilendirilmiştir (Abubakar, 2008). Çocuklara yönelik fiziksel uygunluk normları, genelde, çocukların fiziksel uygunluk düzeylerini değerlendirerek egzersiz ve aktivite programları için reçete yazmak ve zaman içerisinde fiziksel uygunluk değişimlerini denetlemek veya gözlemlemek amacıyla kullanılmaktadır. Aynı zamanda bireysel veya grupların fiziksel uygunluk durumlarını tanımlamak için de dikkate alınır. Bu normlar daima temsil ettiği grubun fiziksel uygunluk değişimlerini denetleme ve tanımlamada gelecekte kritik bir malzeme olarak değerlendirilecektir (Ross vd., 1985; Ross vd., 1987).

$\mathrm{Bu}$ araştırmada, ilkokula giden 8-10 yaş arası kız ve erkek çocuklarının fiziksel ve seçilmiş motorsal performans düzeylerinin bazı sosyo-ekonomik göstergeler ile olan ilişkisini incelemek amaçlanmıştır.

\section{Yöntem}

\subsection{Evren ve Örneklem Açıklaması}

$\mathrm{Bu}$ çalışma Ardahan İl merkezinde devlete ait ilköğretim okullarında eğitim-öğretime devam eden 8,9 ve 10 yaşındaki çocukları kapsayacak şekilde planlandı. Araştırmanın evreni şehir merkezinde bulunan toplam 28 ilkokul olup, çalışmanın yapılacağı örneklem grubu okullar arasından tesadüfi yöntemle seçilen 13 ilkokuldan oluşturuldu. Çalışmaya 239'u kız ve 286'sı da erkek olmak üzere toplam 525 çocuk, Milli Eğitim İl Müdürlüğü, okul yönetimleri ve çocukların ebeveynlerinin onayı ile iştirak ettirildi.
Araştırmanın yapıldı ̆̆ 1 süreçte Ardahan ilinde bulunan ilkokullardaki (ilçeler dâhil) öğrenci sayısı 5503 olarak verilmiştir (Erişim tarihi 18.12.2018) http://ardahan.meb.gov.tr/meb. Bu çerçevede ilkokul 2. 3. ve 4. Sınıf öğrencilerinden oluşturulan 525 katılımcının, çalışmanın örneklemi olarak Ardahan İlini temsil edecek yeterlikte bir sayı olduğu kabul edilmiştir (Yazıcıoğlu, 2004).

\section{2. Çalıșma Planlanması}

Çalışmaya katılan hedef gurubun ailelerinin sahip olduğu sosyo-ekonomik statüyü farklılaştıran, aile gelir düzeyi, ailenin ikamet ettiği yerleşim birimi, anne-babanın eğitim düzeyi, ailedeki çocuk sayısı ile ilgili sorular ebeveynler tarafından cevaplandırıldı. Çocuklarının fiziksel ve seçilmiş motorsal performans düzeylerinin ölçümleri hafta içi sabah10:00 ile 12:00 saatleri arasında kendi okullarında çok amaçlı salon, spor salonu veya uygun koridor boşluğunda ve beton zemin üzerinde yapıldı. Araştırmaya katılacak okulların öğrencileri, ölçümlerin yapılacağı günden bir gün önce okul yönetimleri tarafindan haberdar edilerek katılımcıların uygun kıyafetle gelmeleri sağlandı.

\subsection{Etik}

Resmi izinler sonrasında yapılacak olan çalışma ile ilgili öğrenci velilerine bilgi ve anket metni gönderildi. Sosyoekonomik statü ve ailenin sahip olduğu özel şartlarla ilgili sorulara cevap veren ailelere ait 8,9 ve 10 yaşındaki çocuklar ölçümlere dahil edildi.

\section{4. Ölçümler}

\subsubsection{Sosyo-Ekonomik Statü}

Çalışmaya katılmayı kabul eden ailelerin sahip olduğu sosyo-ekonomik statüyle ilgili olarak sorulan sorular; İkamet ettikleri yerleşim yeri, aile gelir düzeyi, anne ve baba eğitim düzeyleri ile ailedeki çocuk sayısı şeklinde tasarlandı.

\subsubsection{Antropometrik Ölçümler}

Çocukların boyları $\pm 1 \mathrm{~mm}$ hassasiyette holtain marka (Made In England) stadiometre ve vücut ağırlıkları eşofman altı ve tişört ile ayakkabısız olarak $0,1 \mathrm{~kg}$ hassasiyetinde fakir marka (Made In Germany) baskül ile ölçüldü. Vücut yağ oranları belirlemek için holtain skinfold caliper (Made In England) ile triceps ve supscpula bölgesinden alınan yă ölçümleri yapıldı. Ölçümler baskın olmayan uzuv tarafından ve çıplak ten üzerinden alındı. Tahmini vücut yağ \% (Estimate body fat \%);

-Kız çocuklarında; vücut yağ yüzdesi $(\%)=1.33$ $(\text { tric+subsc) - } 0.013 \text { (tric+subsc) })^{2}-2.5$ formülü,

-Erkek Çocuklarında; vücut yağ yüzdesi (\%) = 1.21 (tric+subsc) - 0.008 (tric+subsc) ${ }^{2}-1.7$ formülü ile hesapland1 (Slaughter vd., 1988).

\subsection{Motorsal Beceri Testleri}

Testler öncesi gruplar halinde 1sınmaya başlamadan önce hangi testlerin/ölçümlerin nasıl yapılacağı ile ilgili bilgiler katılımcı çocuklara anlatıldı. Motor beceri testleri öncesi 1sınma (warm-up) safhasında her biri 5-7 kişiden oluşan 
gruplara 8 dakika boyunca yürüme, düşük ve orta şiddette koşular, iki ayak birlikte öne atlama, tek ayağı kaldırarak dengede durma hareketleri ile eklemlere ve karın bölgesine yönelik esnetme ve germe egzersizleri yaptırıldı.

\subsubsection{El Pençe Kuvvet Testi}

El dinamometresi (Takei, Made In Japan) deneğin el ayası uzunluğuna göre ayarlandı. Kolunu dirsekten bükmeden sağ ve sol el pençe kuvvetlerinin ölçümü yapıldı. Her iki el için yapılan iki tekrardan iyi olanı bireysel bilgi formuna kaydedildi.

\subsubsection{Durarak Uzun Atlama}

Teste tabi olan katılımcıya, ayak uçları sıfır başlangıç noktasını geçmeyecek şekilde pozisyon aldırılır. Sonrasında durduğu yerden hız almadan olabildiğince ileriye doğru atlaması istendi. Atlama sonrası arkada kalan ayağının arka topuk kısmı hizasından tebeşir veya renkli kalemle işaretleme yapıldı. Daha sonra başlangıç noktası ile atlama sonrası işaretlenen mesafe arası ölçüldü. $\mathrm{Bu}$ işlem 45-60 saniye aradan sonra tekrarlatıldı ve iyi olan sonuç bireysel bilgi formuna kaydedildi.

\subsubsection{Esneklik, Otur Eriş Testi}

Ölçüm için $55 \mathrm{~cm}$ uzunluğunda, $45 \mathrm{~cm}$ genişliğinde $32 \mathrm{~cm}$ yüksekliğinde, test sehpası kullanıldı. Ölçüm sehpasının üst yüzeyi, ayakların dayandığı yüzeyden $15 \mathrm{~cm}$ daha dışarıda olacak şekilde dizayn edildi ve üst yüzey zeminine $0-50 \mathrm{~cm}$ ' lik polyester şerit metre yerleştirildi. Ölçümler dizler bükülmeden ayak tabanları sehpaya dayandırılarak başlatıldı. Esneklik ölçümü katılımcılardan mevcut pozisyonlarını bozmadan kollarını düz bir şekilde sehpa üzerinde hareketli olan çubuğu ileriye doğru götürebilecekleri en son noktaya kadar sürüklemeleri istenerek yaptırıld1. 30 saniye aralıkla yapılan 2 tekrardan iyi olan ölçüm bireysel bilgi formuna kaydedildi.

\subsubsection{Mekik Sürat Koşusu Testi $5 \times 10 m$}

Sürat ve çabukluk $5 \times 10 \mathrm{~m}$ testi ile değerlendirildi (Philippaerts vd., 2006). Test $10 \mathrm{~m}$ uzunluğunda başlangıcı ve sonu önceden renkli kâğıt bantla belirlenmiş, zemini düz ve sert olan spor salonunda yaptırıldı. 10 metrenin başlangıcında (en az $3 \mathrm{~m}$ ) ve özellikle sonunda (en az $6 \mathrm{~m}$ ) güvenlik alanı oluşturuldu. Zaman casio marka kronometre ile takip edildi (start-stop). Testin uygulamasındaki ikinci tekrar tam dinlenme sonrası (nabız; atım/dakika < 110) yaptırıld1. Derecelerden iyi olan bireysel bilgi formuna kaydedildi.

\subsubsection{Mekik Testi}

Katılımc1, yere sabit olarak tutturulmuş cimnastik minderi üzerine sırt üstü yatarak elleri ensede kilitler. Ayak tabanı mindere yapışı k ve dizler $90^{\circ}$ bükülü vaziyette pozisyon alınır. Ayakların yerde sabit durması için yardımcı kişi ayaküstlerinden baskı uygular. Başla komutu ile katılımcının 60 saniye boyunca mekik hareketini yapması istenir. İlk 30 saniye, ikinci 30 saniye ve sonrasinda yapılan toplam mekik sayısı ayrı ayrı bireysel bilgi formuna kaydedildi.

\subsubsection{Flamingo Denge Testi}

Flamingo denge testi; $50 \mathrm{~cm}$ uzunluğunda, $4 \mathrm{~cm}$ yüksekliğinde, $3 \mathrm{~cm}$ genişliğinde kiriş şeklindeki platform üzerinde 1 dakika süresince tek ayaküstünde bir yere dokunmadan durabilme temeline dayalı bir denge testidir. $\mathrm{Bu}$ çalışmada kullanılan kiriş platform üzeri düz ve kaymayacak bir yapıda olup ahşaptan imal edilmiştir. $15 \mathrm{~cm}$ uzunluğunda ve $2 \mathrm{~cm}$ genişliğindeki 2 ayak, kirişin baş taraflarına monte edilmesi test aletinin dengeli bir şekilde zeminde durmasını sağlar. Teste başlamadan öce serbest olan bacağı aynı taraftaki elin yardımı ile bükülü vaziyette kalçaya yakın bir şekilde tutulur. Katılımcı, yardımcı aracılığı ile teste hazır bir konuma geldikten sonra süre başlar ve denge aletinde 1 dakika süresince tercih ettiği ayak üzerinde pozisyonunu bozmadan durmaya çalışır. Elle tutulan bükülü bacağın bırakılması, denge aletinden düşme veya vücudun herhangi bir parçasının zemine değmesi halinde test protokolü dişına çıkılmış olur ve zaman durdurulur. Duruş pozisyonu başlangıç aşamasına getirildiğinde zaman yeniden işlemeye devam eder. İlk 30 saniye içerisinde 15 hata yapilırsa test durdurulur ve katılımcıya sıfir puan verilir (Tsigilis vd., 2008; Council of Europe, 1988).

\subsection{Veri Yönetimi ve Analizler}

İstatistiksel analizlerin değerlendirilmesi Statistical Package for Social Sciences (SPSS) 23.0 programı aracılığ1 ile yapıldı. Çalışmada fiziksel ve motorsal özellikler ile sosyoekonomik statüsü farklı olan grupların değerlendirilmesinde tanımlayıcı istatistikler, çoklu karşılaştırmalarda ise One Way Anova (tek yönlü varyans) analizi kullanıldı. Gruplar arası farklılıkların belirlenmesinde homojen olan guruplar için Tukey HSD testi, homojen olmayan guruplar için ise Tamhane's T2 çoklu karşılaştırma testi tercih edildi. Sosyoekonomik statüyü farklılaştıran değişkenler arasındaki ilişki pearson korelasyon katsayısına bakılarak yapıld1 ve istatistiksel değerlendirmelerde anlamlılık düzeyi $\mathrm{p}<0.05$ olarak kabul edildi.

\section{Bulgular}

Farklı sosyo-ekonomik statünün 8-10 yaş arası çocuklarda ölçülen bazı fiziksel ve motorsal performans üzerindeki etkinliğini incelemek için planlanan bu çalışmada herbir çocuğun; boy, vücut ağırlığı ve vücut yağ yüzdesi ile durarak uzun atlama, el pençe kuvveti, esneklik, mekik çekme ve $5 \mathrm{x}$ $10 \mathrm{~m}$ çeviklikle kombine edilmiş hız performansları ölçüldü (Tablo 1). Ailelerin sosyo-ekonomik göstergelerinden gelir durumu, yerleşim birimi ve anne-babanın eğitim düzeylerinin kategorisel olarak farklılaşmasının dağılım yüzdeleri Tablo 2'de verildi. Ailelerin sosyo-ekonomik statülerini farklılaştıran "aylık geliri düzeyi" ve "ikamet edilen yerleşim biriminin" çocuklarda ölçülen bazı fiziksel ve motorsal özellikler üzerindeki etkinliği Tablo 4 ve Tablo 5 'de gösterildi.

8-10 yaş aralığındaki kız ve erkek çocuklarının bazı fiziksel ve motorsal performans değerlerinin ortalamaları incelendiğinde yaş, vücut ağırlığı, boy ve esneklik özellikleri benzer, bulundu. Vücut yağ yüzdesinin anlamlı seviyede kız çocuklarında yüksek olduğu, flamingo denge testinde ise yapılan hata sayısı bakımından bu defa kız çocuklarının daha 
az hata puanı aldıkları tespit edildi (Tablo 1; p<0,05). Erkek çocukların sağ ve sol el pençe kuvveti, durarak uzun atlama ve mekik çekme bakımından anlamlı düzeyde kız çocuklarından daha iyi oldukları tespit edildi (Tablo 1; $\mathrm{p}<0,05)$.

Sosyo-ekonomik göstergelerden gelir düzeyi, ikametgâh adresi, anne ve babanın eğitim durumları ile bu değişkenlerin kategorilendirilmiş alt sınıflar içerisindeki frekans ve yüzdeleri Tablo 2' de verilmiştir.

Çalışmaya katılan çocukların ailelerinin \% 39,2'sinin aylık 0-999 Türk Lirası (TL) geliri olan en alt gelir grubunda, $\% 12,4$ 'ünün ise 3000 ve üzeri TL geliri olan en üst gelir grubunda olduğu, yerleşim birimi bakımından ise ailelerin \% 53,5'inin merkez mahallede, \%18,5'inin ise köyde ikamet ettiği tespit edilmiştir (Tablo 2).

Tablo 1: 8-10 Yaş Arası Kız ve Erkek Çocuklarının Ölçülen Fiziksel ve Motorsal Özelliklerinin Ortalama Değerleri

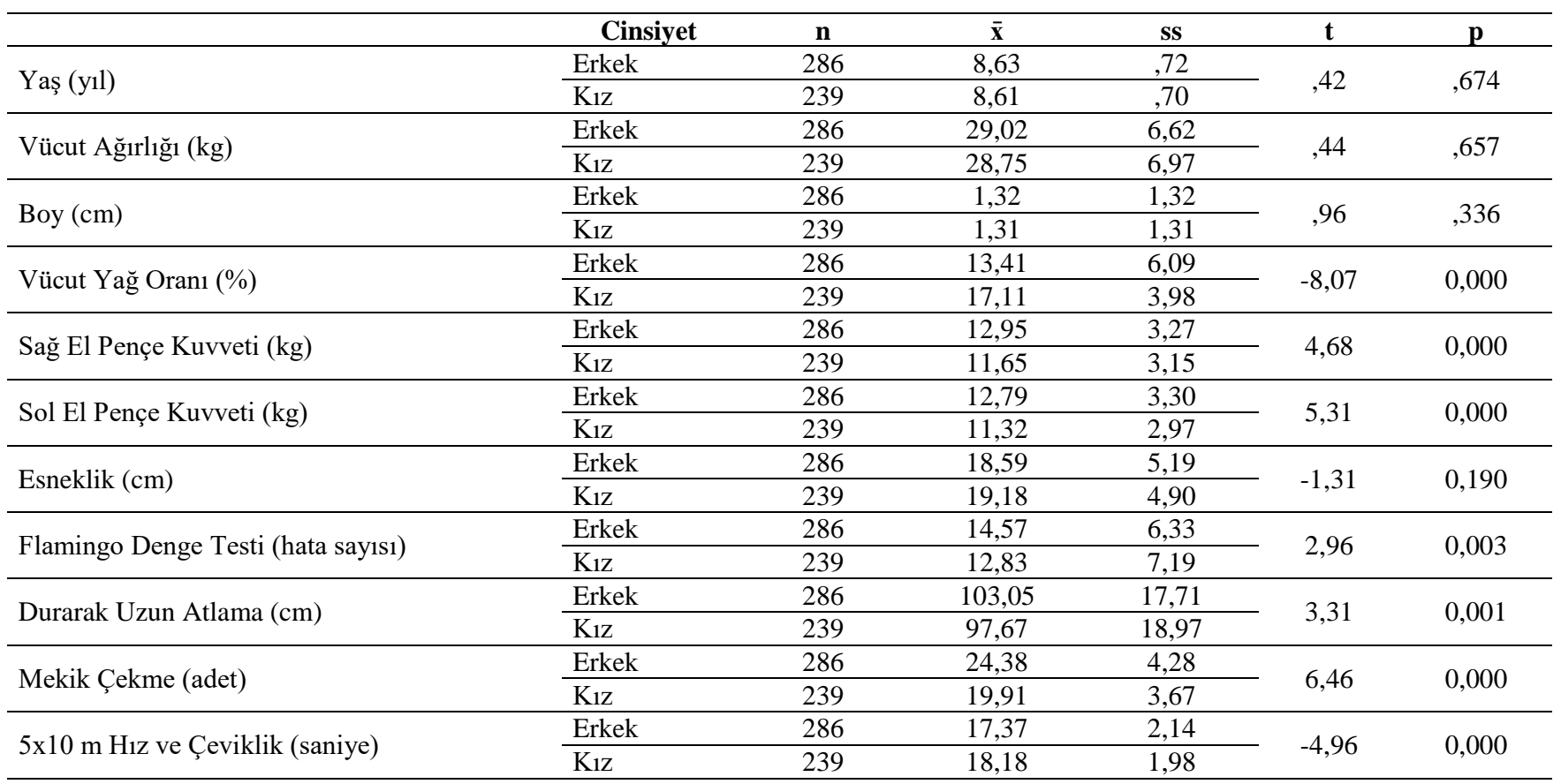

Tablo 2: Sosyo-Ekonomik Göstergelerden Gelir Düzeyi, İkametgâh Adresi, Anne ve Babanın Eğitim Durumları İle İlgili Değişkenlerin Kategorilendirilmiş Alt Sınıflar İçerisindeki Frekans ve Yüzdeler

\begin{tabular}{|c|c|c|c|c|}
\hline & & f & $\%$ & Birikimli Yüzde \\
\hline \multirow{5}{*}{$\begin{array}{l}\text { Aylık Gelir Düzeyi } \\
\text { (TL) }\end{array}$} & $0-999$ & 206 & 39,2 & 39,2 \\
\hline & $1000-1999$ & 175 & 33,3 & 72,6 \\
\hline & $2000-2999$ & 79 & 15,0 & 87,6 \\
\hline & 3000 ve üzeri & 65 & 12,4 & 100,0 \\
\hline & Total & 525 & 100,0 & \\
\hline \multirow{4}{*}{ İkametgâh Adresi } & Merkez mahalle & 281 & 53,5 & 53,5 \\
\hline & Merkezden uzak mahalle & 147 & 28,0 & 81,5 \\
\hline & Köy (Merkeze bağlı) & 97 & 18,5 & 100,0 \\
\hline & Total & 525 & 100,0 & \\
\hline \multirow{4}{*}{$\begin{array}{l}\text { Eğitim Düzeyi } \\
\text { (Baba) }\end{array}$} & İlköğretim & 240 & 45,7 & 45,7 \\
\hline & Lise & 193 & 36,8 & 82,5 \\
\hline & Ön lisans/lisans ve lisansüstü & 92 & 17,5 & 100,0 \\
\hline & Total & 525 & 100,0 & \\
\hline \multirow{4}{*}{$\begin{array}{l}\text { Eğitim Düzeyi } \\
\text { (Anne) }\end{array}$} & İlköğretim & 349 & 66,5 & 66,5 \\
\hline & Lise & 133 & 25,3 & 91,8 \\
\hline & Ön lisans/lisans ve lisansüstü & 43 & 8,2 & 100,0 \\
\hline & Total & 525 & 100,0 & \\
\hline
\end{tabular}

Eğitim düzeyi bakımından anne ve babanın sırası ile en çok ilköğretim sonra lise ve sonra da ön lisans / lisans / lisansüstü mezunu kategorisinde yer aldığı görülmüştür (Tablo 2). Ailelerin sosyo-ekonomik statüsünü farklılaştıran aile gelir düzeyi, ikamet edilen yerleşim birimi, anne ve babanın eğitim düzeyi ve ailedeki çocuk sayısı değişkenlerinden her birinin diğer değişkenler ile ilgileşim düzeylerinin gerek pozitif $(+)$ ve gerekse negatif (-) yönde anlamlı olduğu görülmüştür (Tablo 3).

Sosyo-ekonomik statüyü farklılaştıran unsurlardan biri olan aile gelir düzeyinin seçilmiş bazı fiziksel ve motor beceri performansı üzerine etkisine bakıldığında, bu özelliğin 8-10 yaş arası erkek çocukların vücut ağırlığı, boy ve uzan eriş (esneklik) özellikleri üzerinde anlamlı bir etki oluşturduğu $(p<0,05), k ı$ çocuklarında ise oluşan etkinin anlamlı düzeyde olmadığı tespit edildi (Tablo 4). 
Tablo 3: 8-10 Yaş Grubu Çocukların Ailelerinin Sahip Oldukları Aile Gelir Seviyesi, İkametgâh Adresi, Anne ve Babanın Eğitim Düzeyleri ve Ailedeki Çocuk Sayısı Özellikleri Arasındaki İlişki

Kız ve erkek çocukların ikamet edilen yerleşim yerinin çeviklik testinde adrese göre kategorize edilmiş hem erkek

\begin{tabular}{|c|c|c|c|c|c|c|}
\hline & & $\begin{array}{l}\text { Aylık Gelir } \\
\text { Düzeyi }\end{array}$ & $\begin{array}{c}\text { İkametgâh } \\
\text { Adresi }\end{array}$ & $\begin{array}{c}\text { Eğitim Düzeyi } \\
\text { Baba }\end{array}$ & $\begin{array}{c}\text { Eğitim Düzeyi } \\
\text { Anne }\end{array}$ & $\begin{array}{c}\text { Ailedeki Çocuk } \\
\text { Sayısı }\end{array}$ \\
\hline \multirow{2}{*}{ Aylık Gelir Düzeyi } & $\mathbf{r}$ & 1,000 &,$- \mathbf{3 6 0} 0^{* *}$ &, $\mathbf{5 0 1}^{* *}$ & $\mathbf{4 6 3}^{* *}$ &,$- 207^{* *}$ \\
\hline & $P$ & &, 000 &, 000 &, 000 &, 000 \\
\hline \multirow{2}{*}{ İkametgâh Adresi } & $\mathbf{r}$ & & 1,000 &,$- 260^{* *}$ &,$- 293^{* *}$ &, $207^{* * *}$ \\
\hline & $P$ & & &, 000 &, 000 &, 000 \\
\hline \multirow{2}{*}{ Eğitim Düzeyi Baba } & $\mathbf{r}$ & & & 1,000 &, $\mathbf{4 6 5}^{* *}$ &,$- 268^{* *}$ \\
\hline & $P$ & & & &, 000 &, 000 \\
\hline \multirow{2}{*}{ Eğitim Düzeyi Anne } & $\mathbf{r}$ & & & & 1,000 &,- 331 $^{* * *}$ \\
\hline & $P$ & & & & &, 000 \\
\hline \multirow{2}{*}{ Ailedeki Çocuk Sayısı } & $\mathbf{r}$ & & & & & 1,000 \\
\hline & $P$ & & & & &, 000 \\
\hline
\end{tabular}

Aylık Gelir Düzeyi (Türk Lirası) Gruplar: 1) 0-999, 2) 1000-1999, 3) 2000-2999, 4) 3000 ve Üzeri

İkametgâh adresi: 1.şehir merkezi, 2.merkeze uzak mahalle, 3.köy (merkez bağl1)

Eğitim Düzeyi Baba: 1.ilköğretim, 2.lise, 3. ön lisans/lisans/lisansüstü

Ĕ̆itim Düzeyi Anne: 1.ilköğretim, 2.lise, 3.ön lisans/lisans/lisansüstü

Ailedeki çocuk sayısı: $1,2,3,4, \ldots$

farklılığına dayanılarak incelenen bazı fiziksel ve motorsal beceri özelliklerinin birçoğunda anlamlı değişimlerin olduğu tespit edildi ( $<<0,05$; Tablo 5). Vücut ağırlığı, boy, vücut yağ yüzdesi, denge yeteneği ve $5 \times 10 \mathrm{~m}$ hiz ve hem de kızların gruplarında anlamlı farlılıklar bulunurken, sol el pençe kuvveti ile esneklik testlerinde sadece erkek çocuklarında gruplar arasında anlamlı farlılıklar tespit edildi $(\mathrm{p}<0,05$; Tablo 5).

Tablo 4. 8-10 Yaş Grubu Çocuklarda Farklı Aile Gelir Düzeyleri (Türk Lirası) İle Ölçülen Bazı Fiziksel ve Motorsal Özellikler Arasındaki İlişki

\begin{tabular}{|c|c|c|c|c|c|c|c|c|c|c|c|}
\hline & & \multicolumn{5}{|c|}{ Erkek çocuklar } & \multicolumn{5}{|c|}{ Kız çocuklar } \\
\hline & & $\mathbf{n}$ & $\overline{\mathbf{x}}$ & ss & $\mathbf{p}$ & fark & $\mathbf{n}$ & $\overline{\mathbf{x}}$ & ss & $\mathbf{p}$ & fark \\
\hline \multirow{5}{*}{ Vücut Ağırlığı (kg) } & 1) 0-999 & 123 & 27,40 & 6,12 & \multirow{5}{*}{0,002} & \multirow{5}{*}{$\begin{array}{l}1-3 \\
1-4\end{array}$} & 83 & 29,12 & 8,41 & \multirow{5}{*}{0,383} & \multirow{5}{*}{-} \\
\hline & 2) 1000-1999 & 92 & 29,70 & 6,80 & & & 83 & 28,66 & 5,65 & & \\
\hline & 3) 2000-2999 & 31 & 30,94 & 6,36 & & & 48 & 27,47 & 5,13 & & \\
\hline & 4) 3000 ve üzeri & 40 & 30,91 & 6,93 & & & 25 & 30,28 & 8,67 & & \\
\hline & Total & 286 & 29,02 & 6,61 & & & 239 & 28,75 & 6,98 & & \\
\hline \multirow{5}{*}{ Boy $(\mathrm{cm})$} & 1) $0-999$ & 123 & 129,90 & 0,09 & \multirow{5}{*}{0,001} & \multirow{5}{*}{$\begin{array}{l}1-3 \\
1-4\end{array}$} & 83 & 130,80 & 0,12 & \multirow{5}{*}{0,268} & \multirow{5}{*}{-} \\
\hline & 2) 1000-1999 & 92 & 132,00 & 0,08 & & & 83 & 131,40 & 0,08 & & \\
\hline & 3) 2000-2999 & 31 & 134,70 & 0,06 & & & 48 & 129,40 & 0,07 & & \\
\hline & 4) 3000 ve üzeri & 40 & 134,70 & 0,07 & & & 25 & 133,70 & 0,08 & & \\
\hline & Total & 286 & 131,80 & 0,08 & & & 239 & 131,00 & 0,09 & & \\
\hline \multirow{5}{*}{ Vücut Yağ Oranı (\%) } & 1) $0-999$ & 123 & 12,89 & 6,07 & \multirow{5}{*}{0,563} & \multirow{5}{*}{-} & 83 & 16,86 & 4,61 & \multirow{5}{*}{0,145} & \multirow{5}{*}{-} \\
\hline & 2) 1000-1999 & 92 & 13,68 & 6,58 & & & 83 & 17,05 & 3,36 & & \\
\hline & 3) 2000-2999 & 31 & 14,49 & 5,14 & & & 48 & 16,76 & 3,05 & & \\
\hline & 4) 3000 ve üzeri & 40 & 13,53 & 5,70 & & & 25 & 18,83 & 4,87 & & \\
\hline & Total & 286 & 13,41 & 6,09 & & & 239 & 17,11 & 3,98 & & \\
\hline \multirow{5}{*}{$\begin{array}{l}\text { Sağ El Pençe Kuvveti } \\
(\mathrm{kg})\end{array}$} & 1) $0-999$ & 123 & 12,92 & 3,26 & \multirow{5}{*}{0,197} & \multirow{5}{*}{-} & 83 & 11,55 & 3,33 & \multirow{5}{*}{0,260} & \multirow{5}{*}{-} \\
\hline & 2) 1000-1999 & 92 & 12,56 & 3,11 & & & 83 & 11,85 & 2,92 & & \\
\hline & 3) 2000-2999 & 31 & 13,03 & 3,27 & & & 48 & 11,05 & 2,58 & & \\
\hline & 4) 3000 ve üzeri & 40 & 13,89 & 3,58 & & & 25 & 12,45 & 3,29 & & \\
\hline & Total & 286 & 12,95 & 3,27 & & & 239 & 11,65 & 3,05 & & \\
\hline \multirow{5}{*}{$\begin{array}{l}\text { Sol El Pençe Kuvveti } \\
(\mathrm{kg})\end{array}$} & 1) 0-999 & 123 & 12,83 & 3,62 & \multirow{5}{*}{0,639} & \multirow{5}{*}{ - } & 83 & 11,18 & 3,08 & \multirow{5}{*}{0,052} & \multirow{5}{*}{-} \\
\hline & 2) 1000-1999 & 92 & 12,47 & 2,83 & & & 83 & 11,75 & 2,92 & & \\
\hline & 3) 2000-2999 & 31 & 13,22 & 3,13 & & & 48 & 10,43 & 2,55 & & \\
\hline & 4) 3000 ve üzeri & 40 & 13,07 & 3,41 & & & 25 & 12,03 & 3,19 & & \\
\hline & Total & 286 & 12,79 & 3,30 & & & 239 & 11,32 & 2,97 & & \\
\hline
\end{tabular}




\begin{tabular}{|c|c|c|c|c|c|c|c|c|c|c|c|}
\hline \multirow{5}{*}{$\begin{array}{l}\text { Durarak Uzun Atlama } \\
\%(\mathrm{~cm})\end{array}$} & 1) 0-999 & 123 & 101,98 & 17,87 & \multirow{5}{*}{0,062} & \multirow{5}{*}{-} & 83 & 98,83 & 18,09 & \multirow{5}{*}{0,516} & \multirow{5}{*}{-} \\
\hline & 2) $1000-1999$ & 92 & 103,06 & 19,76 & & & 83 & 97,48 & 21,12 & & \\
\hline & 3) 2000-2999 & 31 & 98,84 & 16,66 & & & 48 & 94,44 & 17,41 & & \\
\hline & 4) 3000 ve üzeri & 40 & 109,60 & 14,79 & & & 25 & 100,68 & 17,96 & & \\
\hline & Total & 286 & 103,05 & 18,14 & & & 239 & 97,66 & 19,04 & & \\
\hline \multirow{5}{*}{$\begin{array}{l}\text { Flamingo Denge } \\
\text { Testi (hata say1s1) }\end{array}$} & 1) $0-999$ & 123 & 14,58 & 5,98 & \multirow{5}{*}{0,120} & \multirow{5}{*}{-} & 83 & 12,94 & 6,43 & \multirow{5}{*}{0,765} & \multirow{5}{*}{-} \\
\hline & 2) 1000-1999 & 92 & 13,99 & 6,09 & & & 83 & 12,80 & 8,63 & & \\
\hline & 3) 2000-2999 & 31 & 17,03 & 7,24 & & & 48 & 12,09 & 5,62 & & \\
\hline & 4) 3000 ve üzeri & 40 & 13,96 & 6,89 & & & 25 & 13,96 & 6,84 & & \\
\hline & Total & 286 & 14,57 & 6,33 & & & 239 & 12,83 & 7,15 & & \\
\hline \multirow{5}{*}{$\begin{array}{l}\text { Uzan-Eriş Testi } \\
\text { Esneklik }(\mathrm{cm})\end{array}$} & 1) $0-999$ & 123 & 19,20 & 4,58 & \multirow{5}{*}{0,001} & \multirow{5}{*}{$\begin{array}{l}1-3 \\
2-3 \\
3-4\end{array}$} & 83 & 18,38 & 4,58 & \multirow{5}{*}{0,057} & \multirow{5}{*}{-} \\
\hline & 2) $1000-1999$ & 92 & 18,91 & 5,35 & & & 83 & 20,12 & 4,50 & & \\
\hline & 3) 2000-2999 & 31 & 15,16 & 4,83 & & & 48 & 19,55 & 5,17 & & \\
\hline & 4) 3000 ve üzeri & 40 & 18,65 & 5,46 & & & 25 & 17,85 & 5,73 & & \\
\hline & Total & 286 & 18,59 & 5,11 & & & 239 & 19,16 & 4,85 & & \\
\hline \multirow{5}{*}{ Mekik Çekme (adet) } & 1) 0-999 & 123 & 24,47 & 8,83 & \multirow{5}{*}{0,763} & \multirow{5}{*}{-} & 83 & 20,23 & 7,60 & \multirow{5}{*}{0,506} & \multirow{5}{*}{-} \\
\hline & 2) $1000-1999$ & 92 & 24,22 & 9,06 & & & 83 & 20,09 & 6,88 & & \\
\hline & 3) 2000-2999 & 31 & 23,23 & 5,71 & & & 48 & 18,56 & 6,17 & & \\
\hline & 4) 3000 ve üzeri & 40 & 25,37 & 8,11 & & & 25 & 20,80 & 7,77 & & \\
\hline & Total & 286 & 24,38 & 8,50 & & & 239 & 19,90 & 7,09 & & \\
\hline \multirow{5}{*}{$\begin{array}{l}5 \times 10 \text { m Hiz ve } \\
\text { Çeviklik (sn) }\end{array}$} & 1) 0-999 & 123 & 17,15 & 2,29 & \multirow{5}{*}{0,280} & \multirow{5}{*}{-} & 83 & 17,97 & 1,73 & \multirow{5}{*}{0,386} & \multirow{5}{*}{-} \\
\hline & 2) $1000-1999$ & 92 & 17,56 & 1,70 & & & 83 & 18,18 & 1,77 & & \\
\hline & 3) 2000-2999 & 31 & 18,18 & 1,77 & & & 48 & 18,51 & 1,59 & & \\
\hline & 4) 3000 ve üzeri & 40 & 16,98 & 1,53 & & & 25 & 18,27 & 1,83 & & \\
\hline & Total & 286 & 17,37 & 1,99 & & & 239 & 18,18 & 1,73 & & \\
\hline
\end{tabular}

Tablo 5. 8-10 Yaş Arası Çocuklarda Aile İkametgâh Adresi İle Ölçülen Bazı Fiziksel ve Motor Yetenekler Arasındaki İlişki

\begin{tabular}{|c|c|c|c|c|c|c|c|c|c|c|c|}
\hline & & \multicolumn{5}{|c|}{ Erkek çocuklar } & \multicolumn{5}{|c|}{ Kız çocuklar } \\
\hline & & $\mathbf{n}$ & $\overline{\mathbf{x}}$ & ss & $\mathbf{p}$ & fark & $\mathbf{n}$ & $\overline{\mathbf{x}}$ & ss & $\mathbf{p}$ & fark \\
\hline \multirow{4}{*}{ Vücut Ağırlığı (kg) } & 1.Şehir merkezi & 150 & 30,49 & 7,32 & \multirow{4}{*}{0,000} & \multirow{4}{*}{$\begin{array}{l}1-2 \\
1-3\end{array}$} & 131 & 30,00 & 7,21 & \multirow{4}{*}{0,007} & \multirow{4}{*}{$1-2$} \\
\hline & $\begin{array}{l}\text { 2.Şehir merkezinden } \\
\text { uzak mahalle }\end{array}$ & 85 & 27,67 & 6,08 & & & 62 & 26,79 & 5,40 & & \\
\hline & 3.Köy & 51 & 26,90 & 3,75 & & & 46 & 27,85 & 7,61 & & \\
\hline & Total & 286 & 29,02 & 6,62 & & & 239 & 28,75 & 6,99 & & \\
\hline \multirow{4}{*}{ Boy $(\mathrm{cm})$} & 1.Şehir merkezi & 150 & 134,1 & 0,07 & \multirow{4}{*}{0,000} & \multirow{4}{*}{$\begin{array}{l}1-2 \\
1-3\end{array}$} & 131 & 133,0 & 0,08 & \multirow{4}{*}{0,020} & \multirow{4}{*}{$1-2$} \\
\hline & $\begin{array}{l}\text { 2.Şehir merkezinden } \\
\text { uzak mahalle }\end{array}$ & 85 & 130,2 & 0,10 & & & 62 & 129,1 & 0,09 & & \\
\hline & 3.Köy & 51 & 129,1 & 0,07 & & & 46 & 130,2 & 0,12 & & \\
\hline & Total & 286 & 132,1 & 0,08 & & & 239 & 131,1 & 0,09 & & \\
\hline \multirow{4}{*}{$\begin{array}{l}\text { Vücut Yağ Oranı } \\
(\%)\end{array}$} & 1.Şehir merkezi & 150 & 14,00 & 6,98 & \multirow{4}{*}{0,017} & \multirow{4}{*}{$1-3$} & 131 & 17,63 & 3,92 & \multirow{4}{*}{0,043} & \multirow{4}{*}{$1-2$} \\
\hline & $\begin{array}{l}\text { 2.Şehir merkezinden } \\
\text { uzak mahalle }\end{array}$ & 85 & 13,69 & 5,62 & & & 62 & 16,10 & 3,49 & & \\
\hline & 3.Köy & 51 & 11,23 & 2,67 & & & 46 & 16,99 & 4,55 & & \\
\hline & Total & 286 & 13,41 & 6,09 & & & 239 & 17,11 & 3,98 & & \\
\hline \multirow{4}{*}{$\begin{array}{l}\text { Sağ El Pençe } \\
\text { Kuvveti (kg) }\end{array}$} & 1.Şehir merkezi & 150 & 13,26 & 3,34 & \multirow{4}{*}{0,160} & \multirow{4}{*}{-} & 131 & 11,82 & 2,79 & \multirow{4}{*}{0,234} & \multirow{4}{*}{-} \\
\hline & $\begin{array}{l}\text { 2.Şehir merkezinden } \\
\text { uzak mahalle }\end{array}$ & 85 & 12,41 & 3,09 & & & 62 & 11,08 & 2,96 & & \\
\hline & 3.Köy & 51 & 12,93 & 3,31 & & & 46 & 11,92 & 3,80 & & \\
\hline & Total & 286 & 12,95 & 3,27 & & & 239 & 11,65 & 3,06 & & \\
\hline \multirow{4}{*}{$\begin{array}{l}\text { Sol El Pençe } \\
\text { Kuvveti (kg) }\end{array}$} & 1.Şehir merkezi & 150 & 13,31 & 3,42 & \multirow{4}{*}{0,013} & \multirow{4}{*}{$1-2$} & 131 & 11,37 & 2,80 & \multirow{4}{*}{0,783} & \multirow{4}{*}{-} \\
\hline & $\begin{array}{l}\text { 2.Şehir merkezinden } \\
\text { uzak mahalle }\end{array}$ & 85 & 12,02 & 3,14 & & & 62 & 11,10 & 2,86 & & \\
\hline & 3.Köy & 51 & 12,54 & 2,97 & & & 46 & 11,47 & 3,60 & & \\
\hline & Total & 286 & 12,79 & 3,30 & & & 239 & 11,32 & 2,97 & & \\
\hline \multirow{4}{*}{$\begin{array}{l}\text { Durarak Uzun } \\
\text { Atlama } \%(\mathrm{~cm})\end{array}$} & 1.Şehir merkezi & 150 & 101,51 & 18,23 & \multirow{4}{*}{0,318} & \multirow{4}{*}{-} & 131 & 95,60 & 19,67 & & \\
\hline & $\begin{array}{l}\text { 2.Şehir merkezinden } \\
\text { uzak mahalle }\end{array}$ & 85 & 104,89 & 16,66 & & & 62 & 97,77 & 18,26 & 0,055 & - \\
\hline & 3.Köy & 51 & 104,54 & 20,11 & & & 46 & 103,43 & 17,34 & & \\
\hline & Total & 286 & 103,06 & 18,14 & & & 239 & 97,67 & 19,04 & & \\
\hline
\end{tabular}




\begin{tabular}{|c|c|c|c|c|c|c|c|c|c|c|c|}
\hline \multirow{4}{*}{$\begin{array}{l}\text { Flamingo Denge } \\
\text { Testi (hata say1s1) }\end{array}$} & 1.Şehir merkezi & 150 & 14,63 & 5,95 & \multirow{4}{*}{0,023} & \multirow{4}{*}{$2-3$} & 131 & 13,58 & 7,61 & \multirow{4}{*}{0,000} & \multirow{4}{*}{$\begin{array}{l}1-3 \\
2-3\end{array}$} \\
\hline & $\begin{array}{l}\text { 2.Şehir merkezinden } \\
\text { uzak mahalle }\end{array}$ & 85 & 15,66 & 7,13 & & & 62 & 13,97 & 6,89 & & \\
\hline & 3.Köy & 51 & 12,59 & 5,61 & & & 46 & 9,15 & 4,63 & & \\
\hline & Total & 286 & 14,57 & 6,33 & & & 239 & 12,83 & 7,15 & & \\
\hline \multirow{4}{*}{$\begin{array}{l}\text { Uzan-Eriş Testi / } \\
\text { Esneklik }(\mathrm{cm})\end{array}$} & 1.Şehir merkezi & 150 & 17,50 & 5,32 & \multirow{4}{*}{0,001} & \multirow{4}{*}{$\begin{array}{l}1-2 \\
1-3\end{array}$} & 131 & 19,43 & 5,04 & \multirow{4}{*}{0,530} & \multirow{4}{*}{-} \\
\hline & $\begin{array}{l}\text { 2.Şehir merkezinden } \\
\text { uzak mahalle }\end{array}$ & 85 & 19,93 & 4,25 & & & 62 & 19,12 & 4,32 & & \\
\hline & 3.Köy & 51 & 19,58 & 5,18 & & & 46 & 18,49 & 5,02 & & \\
\hline & Total & 286 & 18,59 & 5,12 & & & 239 & 19,17 & 4,85 & & \\
\hline \multirow{4}{*}{ Mekik Çekme (adet) } & 1.Şehir merkezi & 150 & 24,30 & 8,29 & \multirow{4}{*}{0,332} & \multirow{4}{*}{-} & 131 & 19,91 & 6,87 & \multirow{4}{*}{0,788} & \multirow{4}{*}{-} \\
\hline & $\begin{array}{l}\text { 2.Şehir merkezinden } \\
\text { uzak mahalle }\end{array}$ & 85 & 25,31 & 7,96 & & & 62 & 19,50 & 7,18 & & \\
\hline & 3.Köy & 51 & 23,08 & 9,90 & & & 46 & 20,46 & 7,73 & & \\
\hline & Total & 286 & 24,38 & 8,51 & & & 239 & 19,91 & 7,10 & & \\
\hline \multirow{4}{*}{$\begin{array}{l}5 \times 10 \text { m Hiz ve } \\
\text { Çeviklik (sn) }\end{array}$} & 1.Şehir merkezi & 150 & 18,00 & 1,74 & \multirow{4}{*}{0,000} & \multirow{4}{*}{$\begin{array}{l}1-2 \\
1-3\end{array}$} & 131 & 18,78 & 1,63 & \multirow{4}{*}{0,000} & \multirow{4}{*}{$\begin{array}{l}1-2 \\
1-3 \\
2-3\end{array}$} \\
\hline & $\begin{array}{l}\text { 2.Şehir merkezinden } \\
\text { uzak mahalle }\end{array}$ & 85 & 16,74 & 2,29 & & & 62 & 17,97 & 1,78 & & \\
\hline & 3.Köy bağl1 & 51 & 16,56 & 1,49 & & & 46 & 16,79 & 0,93 & & \\
\hline & Total & 286 & 17,37 & 1,99 & & & 239 & 18,18 & 1,73 & & \\
\hline
\end{tabular}

\section{Tartışma}

Fiziksel ve motor beceriler bakımından çocukluk yaşlarından itibaren uygunluk göstergelerinin makul bir aralıkta olması, sağlıklı bir toplumun oluşmasında önemli bir başlangıç olarak kabul edilebilir.

Farklı sosyo-ekonomik statünün 8-10 yaş arası çocuklarda ölçülen bazı fiziksel ve motorsal özellikler üzerindeki etkinliğini incelemek amacı ile planlanan bu çalışmada sosyo-ekonomik yapıyı farklılaştıran özellikle aile gelir düzeyi ve ikamet edilen yerleşim yerinin çocukların bazı fiziksel ve motorsal özellikleri üzerinde anlamlı değişimlere yol açtığ́ görüldü $(\mathrm{p}<0,05$; Tablo 4,5$)$. Aile gelir düzeyi artıkça, benimsenen yerleşim yerinin şehir merkezine doğru kaydığı, çocuk sayısında azalma ve eğitim düzeyinde de anlamlı bir artışın söz konusu olduğu tespit edildi (Tablo 3).

Sosyo-ekonomik statüyü farklılaştıran aile gelir düzeyi faktörü kız çocuklarının fiziksel ve motor beceri performanslarını anlamlı bir şekilde değiştirmez iken, erkek çocuklarının boy, vücut ağırlığı ve esneklik özelliklerini anlamlı düzeyde değiştirdiği tespit edildi ( $p<0,05$; Tablo 4). Boy ve vücut ağırlığı daha yüksek gelir düzeyine sahip çocuklarda, esneklik özelliği ise düşük gelir düzeyine sahip çocuklarda anlamlı derecede yüksek bulundu $(\mathrm{p}<0,05)$. Freitas ve arkadaşlarının Portekiz'e bağlı Madeira Adasında 11 ilçeden 36 okulun 8-, 10-, 12-, 14 ve 16 yaşlarında 256 erkek ve $251 \mathrm{kız}$ (toplam 507) öğrencisinin 3 yıllık takibi ile gerçekleştirdikleri çalışmada, çocukların fiziksel gelişimleri ve motor performanslarının düşük, orta ve yüksek sosyoekonomik statüde olmasina göre anlamlı düzeyde farklılaştığı ortaya koyulmuştur. Aynı çalışmada 7 - 9 yaş aralığındaki çocuklarda (kız ve erkek) hem fiziksel, hem antropometrik hem de motorsal performans bakımından benzerliğin yüksek olduğu rapor edilmiştir.

8-10 yaş arası kız çocuklarında vücut ağırlığı, boy uzunlukları ve motorsal beceriler gelir düzeyi değişkenine göre incelendiğinde benzer bulunurken, erkek çocuklarında boy ve vücut ağırlığı alt gelir düzeyindeki çocuklarda anlamlı bir şekilde düşük bulundu (Tablo 4; $\mathrm{p}<0,05$ ). Erkek çocuklarında uzan eriş testi hariç her iki cinsiyette de vücut yağ yüzdesi, sağ ve sol el pençe kuvveti, durarak uzun atlama, flamingo denge, mekik çekme ve $5 \times 10 \mathrm{~m} \mathrm{~h}$ ız ve çeviklik testlerinde gelir seviyesine göre oluşturulmuş grupların benzer dereceler gösterdikleri $(p>0,05)$ tespit edilmiştir. Vücut ağırlığı ve boy uzunluğu bakımından benzer sonuçlar birçok çalışmada rapor edilmiştir (Olness, 2003; Abubakar, 2008; Malina, 1991; Freitas vd., 2007). Ancak vücut ağırlığı ile ilgili farklı bulgular da rapor edilmiştir. Düşük sosyo-ekonomik grupta yer alan Norveçli çocukların, yüksek sosyo-ekonomik grupta yer alan çocuklardan daha ağır oldukları bildirilmiştir (Brundtland vd., 1980).

Kuzey Amerika'da yapılan başka bir araştırmada düşük gelirli aile çocuklarında (kız ve erkek), subscapular ve triceps bölgelerindeki deri altı yağ kalınlığı miktarının daha yüksek bulunduğu rapor edilmiştir (Garn vd., 1981).

Avrupalı çocuk ve ergenleri konu alan farklı çalışmalardan elde edilen sonuçlarda, sosyo ekonomik statü (SES) ile fiziksel aktivite ve fiziksel uygunluk düzeyleri arasındaki ilişkiler hakkında çok az şeyin bilindiği ve bu ilişkilerin tutarsızlığı bildirilmiştir (Rona, 2000). Farklı bir çalışmada ise kısıtlı sosyal ve ekonomik kaynaklar yetersiz büyüme ve kötü gelişimsel sonuç ile ilişkilendirilmiştir (Abubakar, 2008).

Vücut kompozisyonunu etkileyen sosyo-ekonomik etkenler, ekonomik ve kültürel anlamda farklılık gösteren ülkelerde farklı sonuçlar doğurabilmektedir. Özellikle vücut ağırlığı, toplam vücut yağ oranı ve vücudun belli yerlerindeki deri altı yağ kalınlıkları sosyo-ekonomik statüden olumlu - olumsuz etkilenebilmektedir. Yeterli ve dengeli beslenme ile fiziksel aktiviteye katılım, farklı spor branşlarına ulaşmadaki kolaylık, sağlık ile ilgili olanaklardan faydalanabilme unsurları bu süreci olumluolumsuz etkileyen başlıca nedenler arasında sayılabilir. $\mathrm{Bu}$ çalışmada aile gelir düzeyindense, ikamet edilen yerleşim biriminin fiziksel ve motorsal özellikler üzerinde daha etkili olduğu öne çıkmıştır. Sol el pençe kuvveti ve esneklik testlerinde sadece erkek çocuklarında anlamlı farklılık tespit edilirken $(\mathrm{p}<0,05)$, vücut ağırlığ flamingo denge ve $5 \times 10 \mathrm{~m}$ hiz ve çeviklik özelliklerinde hem kız hem de erkek çocuklarda gruplar arası anlamlı farkl11ıklar elde edildi $(\mathrm{p}<0,05)$. Şehir merkezinde ikamet eden kız ve erkek çocukların vücut ağırlığı, boy ve vücut yağ oranları (\%) özelliği bakımından ya merkezden uzak 
mahallede ya da köyde ikamet edenlere göre daha uzun, daha kilolu ve daha yağlı oldukları tespit edildi (Tablo 5). $\mathrm{Bu}$ durum gelir düzeyi ile ikametgâh adresi arasındaki negatif yönlü ilişkisinin bir yansıması olarak kabul edilebilir. Malina ve Bouchard (1991), şehir merkezinde oturan çocuklarla şehrin kenarlarında veya kırsal kesimlerde oturanlar arasında büyüme ve olgunlaşma farklılıklarının gözlendiğini belirtmişlerdir (Malina, 1991).

İkamet edilen yerleşim birimi ile aylık gelir düzeyi arasındaki anlamlı negatif ilişkiye dayanılarak elde edilen sonuçların birçok çalışma ile paralellik arz ettiği görülmüştür (Tablo 3) (Olness, 2003; Abubakar, 2008; Malina, 1991; Freitas vd., 2007; Pavon vd., 2010). Köylerde ikamet eden erkek çocukların flamingo denge testinde merkezden uzak mahallede oturan çocuklardan, esneklik ve $5 \times 10 \mathrm{~m} \mathrm{~h}$ z ve çeviklik testlerinde ise diğer iki gruptan da daha iyi dereceler çıkardıkları tespit edildi (Tablo 5).

Erden ve Oğuz (2009) yaptıkları çalışmada alt ve üst sosyoekonomik statüdeki 9-10 yaşlarındaki çocukların flamingo denge test sonuçlarını benzer $(p>0,05), 8$ yaş kategorisindeki sonuçları ise alt sosyo-ekonomik grubun lehine bulduklarını ifade etmişlerdir. Aynı çalışmada yüksek sosyo-ekonomik düzeye sahip grubun durarak uzun atlama ve mekik koşusunda daha iyi sonuçlar elde ettikleri bildirilmiştir (Erden vd., 2009).

Bogin ve arkadaşları (2002) insan vücudundaki oranların (oturma yüksekliği) çevresel faktörlere karşı duyarlı olduğunu ileri sürmüş, yüksek, orta ve düşük sosyo ekonomik statüye sahip grupların her birinin karşılaştırmasında istatistiki olarak fark bulduklarını beyan etmişlerdir (Bogin vd., 2002). Ancak ikamet edilen yerleşim birimi dikkate alınarak yapılan bu çalışmada otur eriş (esneklik) testinde elde edilen farklılık, boy uzunluğuna bağlı olarak diğer gruplara göre muhtemelen oturma yüksekliği değeri de iyi olan ve merkezde ikamet eden çocukların aleyhine bulunmuştur.

Özer ve Özdöl (2013) sosyo-ekonomisi farklı toplam 397 erkek ve kız çocuğunun 3 yıl boyunca takip edilen boy, vücut ağırlığı ve yağ yüzdesi değerleri ile çevre ve çap ölçümlerinden neredeyse tamamına yakınında anlamlı farklılıklar bulduklarını rapor etmişlerdir (Özer, 2014).

Motorsal özellikler günlük yaşam içerisinde kullanmaya bağlı olarak farklı düzeylerde performans sergileyebilmektedirler. Kırsalda ikamet eden çocukların günlük yaşamlarında yeterince hatta daha fazlası aktif oldukları muhtemel bir gerçek iken, merkezi yerlerde yaşayan çocukların özel bir çaba ile yaşamlarına hareket katmaları söz konusudur. Aynı zamanda kırsalda veya köyde yaşam, aile ekonomisine özellikle fiziksel uğraşlar aracılığı ile katkı yapma zaruretini daha erken yaşlarda gerekli kılmaktadır. Bu çerçevede erken yaşlardan itibaren çoğunlukla engebeli bir coğrafyada ister oyunlar isterse tarım ve hayvancılıkta bedenen harcanan enerjinin, buralarda ikamet eden çocukların denge, çeviklik, esneklik, dayanıklılık, kuvvet ve bileşenleri gibi motorsal yeteneklerinin birçoğuna olumlu katkı sağladığ1 düşünülmektedir.

Kent yaşamında özel bir çaba olmazsa (düzenli beden eğitimi ve spor uygulamaları, düzenli sportif kurslar...) motorik özelliklerin normal gelişim sürecinde beklenen performansı gösterememesi olası bir sonuç olacaktır.
Planlanmış düzenli motor beceri uygulamaları çocukların fiziksel ve motorsal beceri performanslarını olumlu yönde değiştirecektir.

Nitekim sosyo-ekonomik faktörlerin 9-12 yaş ilkokul çocuklarının fiziksel uygunlukları üzerindeki etkilerini değerlendirmek amacı ile Arjantin'de şehir merkezi ve kenar mahalle olmak üzere iki farklı bölgede yaşayan 145 erkek, 159 kız olmak üzere toplam 294 sağlıklı çocuk üzerinde yapılan bir çalışmada, her iki grup arasında şehir merkezinde yaşayanların lehine anlamlı farklar bulunduğu rapor edilmiştir. $\mathrm{Bu}$ anlamlı farkın erkeklerde hem antropometrik hem de motorik testlerde, kızlarda ise yalnızca motorik testlerde olduğu belirtilmiştir (Perez vd., 1991).

Yüksek gelir grubundan olan çocuklar daha iyi eğitim, daha iyi çocuk bakımı ve sağlık hizmeti almakta, dolayısıyla fiziksel büyüme ve gelişmeleri daha düzenli olmaktadır. Kentlerde yaşayan çocuklar kırsal kesimde yaşayanlara oranla daha iridirler. Dünyada değişik bölgelerde yapılan incelemelerde yüksek ve orta sosyo-ekonomik düzeydeki çocukların düşük sosyo-ekonomik düzeydeki yaşıtlarına oranla daha uzun boylu ve iri yapılı oldukları saptanmıştır (Güler vd., 2004).

Yerleşim biriminin farklılı̆̆ erkek ve kız çocuklarının boy ve vücut ağırlığı üzerinde anlamlı bir etki oluşturmuş ve bu etkinin özellikle şehir merkezinde oturan çocukların lehine olduğu tespit edilmiştir $(\mathrm{p}<0,05)$. Flamingo denge yeteneği ile 5 x 10 m çeviklikle kombine edilmiş hız performansında köyde ikamet eden çocukların üstünlüğü öne çıkmıştır $(\mathrm{p}<0,05)$. Ailelerin gelir düzeylerindeki farklılık k1z çocuklarının fiziksel ve motorsal özelliklerine anlamlı etki yapmaz iken $(\mathrm{p}>0,05)$, gelir düzeyindeki farklılıklar erkek çocuklarının boy, vücut ağırlığı ve esneklik özellikleri üzerinde olumlu-olumsuz yansımalara neden olduğu görülmüştür $(\mathrm{p}<0,05)$.

8-10 yaş arası çocukların sahip oldukları sosyo-ekonomik imkânlar ile bazı fiziksel ve motor beceri özellikleri arasındaki ilişkiyi inceleyen bu çalışmada ailelerin sahip olduğu sosyo-ekonomik statünün belirleyicilerinden olan gelir düzeyi ve ikamet edilen yerleşim biriminin, çocukların fiziksel gelişimi ve motorsal performansı üzerinde olumlu / olumsuz etkiler oluşturduğu tespit edilmiştir.

Özellikle ilköğretim okullarında beden eğitimi ve spor derslerinin ilgili alan öğretmen veya eğitmenleri tarafından amacına uygun bir şekilde yürütülmesi, fiziksel ve motor beceriler bakımından çocukluk yaşlarından itibaren uygunluk göstergelerinin makul bir aralıkta seyretmesine katk1 sağlayacağ1 düşünülmektedir. Bu doğrultuda soğuk hava şartlarına bağlı mevsimsel kısıtlılığın olduğu coğrafyalarda yer alan okulların fiziki anlamda spor salonu ile birlikte planlanması beden eğitimi ve spor derslerinin daha verimli bir şekilde yürütülmesine ve buradan sağlanacak faydaya zemin hazırlayacaktır. 


\section{Kaynakça}

Abubakar A, et al. Socioeconomic status, anthropometric status, and psychomotor development of Kenyan children from resource-limited settings: A pathanalytic study. Early Human Development, 2008; 84: 613-621.

Bogin B, Smith P, Orden AB, Varela Silva MI, Loucky J. Rapid change in height and body proportions of Maya American children. Am J Human Biol., 2002; 14: 753-761.

Brundtland G, Liestøl K, Walløe L. 1980. Height, weight and menarcheal age of Oslo schoolchildren during the last 60 years. Ann Hum Biol 7:307-322.

Council of Europe. Eurofit: European test of physical fitness. Rome: Council of Europe, Committee for the Development of Sport, 1988.

Freitas D, Maia J, Beunen G, Claessens A, Thomis M, Marques AA, Crespo M, Lefevre J. Socio-economic status, growth, physical activity and fitness: The Madeira Growth Study. Annals of Human Biology, January-February, 2007; 34(1): 107-122

Gallahue DL, Ozmun JC. Understanding Motor Development: Infants, Children, Adolescents, Adults (5th Edition). New York: McGraw-Hill, 2002.

Garn S, Hopkins P, Ryan A. 1981. Differential fatness gain of low income boys and girls. Am J Clin Nutr 34:1465-1468.

Güler D, Günay M. Çocuklarda sosyo-ekonomik düzeyin fiziksel uygunluğa etkisinin AAHPERD fiziksel uygunluk test bataryası ile değerlendirilmesi. G.Ü. Kırşehir Eğitim Fakültesi Dergisi, 2004; 5(1): 11-23.

http://ardahan.meb.gov.tr/meb_iys_dosyalar/2017_07/051 55115_2017_TEMMUZ_BRYFYNG.pdf (Date of Access, 18.12.2018, time; 03:55)

https://biruni.tuik.gov.tr/ilgosterge/?locale=tr. Date of Access, 01.03.2019; time, 15:14.

Larson GA, Zaichkowsky LD. Physical Motor and Fitness Development in Children and Adolescents, Journal of Education, 1995; 177: 25-55. Referans4. Gallahue DL, Ozmun JC. Understanding Motor Development: Infants, Children, Adolescents, Adults (5th Edition). New York: McGraw-Hill, 2002.

Malina RM, Bouchard C. Growth Maturation and Physical Activity, Human Kinetics Books, 1991; 391- 414.

Olness K. Effects on brain development leading to cognitive impairments: a worldwide pandemic. J Dev Behav Pediatr, 2003; 24:120-30.

Özer K, Özdöl Y. Three yearly variations of some anthropometric measurement and body composition of children in the different socio-economic status. Procedia-Social and Behavioral Sciences, 2014; 3422-3426.

Pavon JD, Ortega BF, Ruiz RJ, et al. Socioeconomic status influences physical fitness in European adolescents independently of body fat and physical activity: the HELENA Study. Nutr Hosp. 2010; 25(2): 311-316

Perez, GEN, D'angelo CP, Zabala RD. Physical Fitness in Children and Adolescents from Differing Socioecomomic Strata, in Shephard RJ, Parizkova, J. (Eds). Human Growth, Physical Fitness and Nutrition, Med. Sport Sci. Basel, Karger, 1991; 31: 80-98.

Philippaerts RM, Vaeyens R, Janssens M, Renterghem BV, Matthys D, Craen R, Bourgois J, Vrijens J, Beunen G. ve Malina RM. The relationship between peak height velocity and physical performance in youth soccer players. Journal of Sports Sciences, 2006; 24(3): 221-230.

Referans1Slaughter MH, Lohman TG, Boileau RA, Horswill CA, Stillman RJ, Van Loan MD, Bemben DA. Skinfold equations for estimation of body fatness in children and youth. Hum Biol,1988; 60: 709-723.

Referans2. Erden S, Oğuz H, The Investigation of Physical Performance Characteristics of Children From Different Socio-Economic Levels in Bursa. Uludag University Journal of the Education Faculty, 2009; 22(1): 279-292.

Rona R. The impact of the environment on height in Europe: Conceptual and theoretical considerations. Ann Hum Biol., 2000; 27: 111-126.

Ross JG, Dotson CO, Gilbert GG, and Katz SJ. "New Standarts for Fitness Measurement", Journal of Physical Education, Recreation \& Dance, 1985; 56: 62-66.

Ross JG, Pate RR, Delpy LA, Gold RS and Svilar M. "The National Children and Youth Fitness Study II, New Health-Related Fitness Norms", Journal of Physical Education, Recreation \& Dance, NovemberDecember, 1987; 66-70.

Tsigilis NT, Argiris T. The Influence of Multiple Administration of a Psychomotor Test on Performance and Learning. Journal of Strength and Conditioning Research, 2008; 22(6): 1964-1968.

UNICEF. Progress for children: a report card on nutrition, 2006.

Yazıcıŏlu Y, Erdoğan S. SPSS uygulamalı bilimsel araştırma yöntemleri. Ankara: Detay Yayıncılık, 2004; 49-50. 